\title{
Role of Spiritual and Moral Perfection of the Beginning of the Person in the Education
}

\author{
Motornaya Svetlana, Dr. Psychol. Sciences, PhD \\ Sevastopol National Technical University, 299053, Sevastopol, University Street, 33 \\ Email: motornaya@ukr.net
}

Doi:10.5901/mjss.2014.v5n13p222

\begin{abstract}
the key moments of change in ways of pedagogy and education is examined. A theoretical analysis of the role of spiritual and moral principles as an integral component of the training of students in the educational process of the university was conducted. A system of spiritual and moral perfection of the person by means of art, which should form the basis for lectures and workshops with the students, is proposed.
\end{abstract}

Keywords: Pedagogy, Education, Psychocompetization`s Model of Training, Spiritual And Moral Potential, Improvement.

\section{Introduction}

Currently, all progressive thinking mankind, being in the situation need to address global problems, looking for opportunities to resolve them, and the implementation of the path of evolutionary development. Education is, in its superlative degree - higher education - is a prerequisite for the formation of the personality, able to implement the task, and therefore is responsible for evolution. It is necessary that 'the content of education in line psychocompetization process' [Motornaya 2009, p.104]. If it does not, then humanity will evolve blind alley. That's so you should ensure control over the compliance of educational content evolutionary path of development, to apply creativity to change the content of education, the development of teaching forms, methods, tools, and principles that will fit the evolutionary vector of human development. All of the above determines the need in modern teaching practice appears consistent trends update the content of education at all levels, which generate innovative ideas for the transformation of educational programs.

The conditions for the implementation of this ensured that the feature of training at the moment, according to the explication of 'evolutionary models of cone formation' [Motornaya 2010, p.19-20], is a variation of programs and methods of integration of education, which is a reflection of the global and European trends in higher education - and its diversification in its turn, requires the development of performance criteria updating process of teaching, as well as forecasting the development of pedagogy. Natural tendency of all educational programs for the solution of the problem will be the appeal of their content to the means and methods that can revive the spiritual and moral potential of the nation.

Charles Darwin in his "Origin of Man and sexual selection" argued that animal instinct inherent or innate moral sense. Kropotkin in "Origin and development of morality" suggested the group selection and the selection of "instincts of humanity", and the British geneticist and biochemist John Haldane calculated the active selection on the "altruism genes". Thus, today the scientific world notes that the types of congenital intrinsic activity of a person, along with biological and moral presented.

In the philosophical tradition of the twentieth century (Berdjaev, Vernadsky, Lossky, Soloviev, Fedorov, Frank, etc.), man is regarded as a spiritual, creative, open to self-education, self-development, which allows to realize themselves in activities and having the opportunity to create the world in accordance with the ideals of Truth, Goodness, Beauty.

\section{Objectives}

Approach to the person as an absolute value, the motor of evolution, the creator of himself and his position in life compels us to take a fresh look at the essence of perfection of the individual, and to amend the means and methods of influence on personality in the educational process. The latter is an extremely relevant and still unsolved problem in education is a matter of debate, both theoretical and practical studies. Therefore, the aim of our study is to examine the role of spiritual and moral improvement of the individual early in the development of pedagogy and education. 


\section{Methodology}

Qualification today, in our opinion, cannot determine the outcome of the education system. Priority is given according to the documents of UNESCO, organized in a systematic set of demands intellectual, communicative, reflective, moral principles, to successfully implement the activities are not only socially and economically, but also in the cultural contexts. Adopted in 1988 of the Universal Charter of universities noted that the university aims to provide education and training to teach generations to respect the harmony of the world and of life itself. Europe is seeking to become the continent of education with a competitive intellectual, cultural, social, technical expertise, while stressing that education - a public good, and the teaching was, is and will be a moral profession. 'Moral-orientation as a component in the structure of psychological readiness for professional activity formed in high school is a fundamental personality and giving all the other components of the fundamental basis' [Motornaya 1997, p.109].

Spiritual and moral height is an indicator of whole-being-human development. Therefore, education has, first and foremost, to provide the dual development of all aspects, features and abilities of the individual, consistent, high quality continuous updating based on the orientation of education to the changing world, man, and all his relations with the world, let to selfdisclosure, to find fulfillment in the work. Raymundo wrote that "the teaching, learning and research should be inseparable from social impact assessment of these processes, which is a moral dimension, constitutes the essence of the cultural differences of science ... Knowledge, being divided into separate subjects and disciplines, leading to artificial separation of individual approaches to knowledge. As a result, universities produce engineers who do not fancy social impact of their work. Physicians who are not familiar with the psychology of the person - treatment of such doctors often causes psychosomatic illnesses. As for economists, it allows you to their level of training to understand that their work is not neutral, and the effect on the position of society as a whole? We need a new model of training ... that will develop human qualities and ethics "[Raymundo 2003, p. 17].

Technocratic orientation of life, accompanied by a decline of spirituality and morality, ideals, higher values lead to a one-sided development of man, to the narrow, one-sided professionally-activity orientation. Preparing a person for life and work, education and training should include, first of all, to the existence of training and related activities in the world of nature and humanity, the spiritual flow of life. Spiritual man is in a countless variety of its manifestations of mental and activity, including education. Spiritually developed person is going through its involvement in life and of the world, of humanity, of the people and society, people living with him in the world.

By virtue of its primacy of moral criteria unconsciously determine human behavior. Therefore, they say that the first human motivations are the most precious. It was their motive is instinctual drives people, manifested at the levelknowledge is the basis of his evolutionary development. Spirituality draws its origins primarily in stocks of genetic identity. But it can be raised. And to begin this transformation should be from birth. The process of education should take place in a clean atmosphere. It should teach sublimely beautiful. Spiritual man does not become a hypocrite, would not be a coward and a liar. He knows the way to work as a necessary improvement.

However, it should be noted that the moral forms are imparted in a rational way. They are the only reality is the foundation of the inner essence of the person who determines all his actions, when there is a manifestation of high spiritual development of the individual. Without a high spiritual development of the individual cannot be a full employee a professional, as a necessary condition for creativity in any business is a holistic, spiritual development of the individual. Spiritual formation of the individual is paramount, a necessary foundation for all-round development of the individual, selfactualization and self-improvement, and is, in our opinion, are the competence of the person that runs through all of the components of human personality.

In modern pedagogy, man is regarded as the ultimate goal of social development, during which provides the necessary conditions for the full implementation of its internal capacity to achieve harmony in the socio-economic and spiritual life of the field, the highest peak particular individual. As a basis of the whole system of education is being put the humanism principles developed and proven age-old practice. Therefore, from the standpoint of humanism, the ultimate goal of education is that a person can become a full-fledged subject of activity, cognition and communication, that is, free, amateur being responsible for everything that happens in this world.

Humanism implies recognition of the individual as the individual values of all the other people who love them, serve them, and involves teamwork, commitment to community with other people, their mutual support. In social psychology of our people is a moral quality has received a strong impetus for the development. And that, above all, is the idea of catholicity. Therefore, the content of the educational process should, focusing on human values, not to discard all the best that is in the experience of every country, every nation, in every way contrary to update and develop the experience.

Universities, leaving their shadow economy, proclaimed guardians of the traditions of European humanism, which is based on the desire to get to know each other, build international "bridges" with "Peace through Culture". It should 
come out of the University of the man who is not only highly skilled workers, but also has jurisdiction, has a "difficult personal neoplasm readiness for professional work, including the interaction of cognitive, need-motivational, moral orientation and organizational and communicative components that characterize the expression of personality in activity" [Motornaya, Marigodov 2005, p. 130]. Spiritual resources and moral orientation component in the structure of the individual are determining its future activities, contributing to the cognitive component of creativity and creative direction of the evolutionary work, a need-motivational component of personality structure - function monitoring in the implementation of choice, communicative and organizational component - compliance with the gold rules of ethics. The formation of tumors readiness for professional activity takes place in the space of the action of the Laws of the Universe, their knowledge and compliance (comprehension). At the level of human society the knowledge and comprehension of these laws is through culture, which makes the introduction to the personality of the individual in the process of socialization. It is the social components of culture - the norms, values, symbols and language - play a crucial role in the emergence of the individual moral orientation of the component. That's why you need to exercise psychocompetization process: in the space of the action of the Laws of the Universe, these laws should be learned and observed and projected on a pedagogical space in which the educational process. Only when this condition and will form the person possessing the qualities that will help her go through evolution, to lead the people to be able to forecast and strategic management of the future: a graduate of the University should not only be successful, stable today, but effective, that is to be able to make a prediction of success for tomorrow. This is possible with the appearance of his psychological structure of the competence of the stable personality traits that allow a person to act in accordance with the Laws of the Universe and implement a strategic outlook and future management of the evolutionary path of development.

\section{Analysis}

So, we found that the basis for the prosperity of society and mankind on the planet is a manifestation of the spiritual and moral potential of the society. How, then, should be to change the content of pedagogy and education, in what specific ways, methods, tools, principles, it must be shown? In our opinion, the general direction is of the next. The above discussion shows the need for people to adhere to the customs and the traditions established over the centuries. Drawing on past experience, the wisdom of the ages, formed a man's best qualities. Past experience, the custom initially is social, it carries a moral basis. At the base of the custom actions are real people in the most important kinds of situations. It is the spirituality of these acts of humanity customs. Such acts are moral foundation legends that tell of the most important events in the life of the people and the exploits of individual heroes. Tradition having been in the form of oral narrative passed down from generation to generation. Over time, the tradition can be reflected in the folk epics. And the images of these traditions to educate the younger generation, soaking up the moral traits of the characters in the process of experiencing events that appear in the legend. It is the presence of the real action in the tradition of specific people gives him moral strength, makes him listen to and reflect. The legend - experience communicating with the ancestors, it is the assimilation of every human spiritual heritage of their ancestors. The essence of the tradition is to embody a particular person that has been committed to the people of the characters, and the spirit of the ancestors inherited in new generations of humanity. The Company cultivates traits such as courage, sacrifice, courage. Mind, the effect of which is aimed at saving the individual is overcome moral qualities that contribute to the preservation of society. Courage, heroism, self-sacrifice, the cult of the hero becomes the scene of deep moral feelings of all members of society and each individual. In this regard, it is important to in-depth study of the cultural heritage of the people, based on the heroic epic, which is in every nation of the world. The central part of the heroic epic is a feat action hero of the people, which brings its own interests in the public offering. But the most surprising result of that character and personal interests are met, because the condition for their implementation is the happiness of the people to which it belongs to hero. These epics we find everywhere on earth: Edda, the Mahabharata, the Ramayana, the Kalevala, David Sassoon, The Legend of Hiawatha, The Myth of Gilgamesh, the myths of the Scandinavian peoples, Greek, Roman, Slavic folk tales, and many others.

The central part of the heroic epic nations occurring everywhere on the planet - no mean feat - the shortest path to the perfection of the individual, coupled with the self-sacrifice for the sake of others. He is due to fight instinct and morality, emotions and mind. Act for others is an expression of moral goodness, is the victory of spiritual forces, the manifestation of the spirit. The victory of moral good, subordinating reason conjugate to sacrifice, accompanied by a deep emotional shock, the mobilization of all the forces of the body. This condition is accompanied by the actualization of "peak" experiences in the activities of the individual, leading to a state of catharsis, cleansing and renovates personality.

The deep morality has always been an integral feature of our people. This condition is brought up for centuries and is deeply rooted feeding the durability and viability of the nation. Herodotus, visiting the Black Sea coast, noted that the 
tribes inhabiting the area lead a moral and virtuous life. And today it is the integrity of the moral qualities of spirituality is defined by the originality of our people.

However, the modern conditions of life in society arise from the presence of the flow of negative information flowing from the screen televisions, magazines and newspapers proclaiming the freedom of morals and permissiveness in the relationship between the sexes, which helps to change the spiritual principle of our nation. What can cause this trend, they say, first of all scientific data. They warn of the threat of degeneration of the nation following the occurrence of and implementation of the following phenomena. First, this is the change of human consciousness. Psychological science has established that the allowable portion of the negative information in the media may be only $5 \%$, then starts increasing mental instability of the individual, and 50-60 \% comes "revolution of consciousness": the social components of culture: the criteria, values, norms, language and symbols of perceived a man with exactly the opposite. In our time, this figure is often as high as $80 \%$. And we begin to wonder why the younger generation is formed, which has a negative criterion, anti-human standards, which no system of moral values, spirituality, etc. Further, in the last century, in 1899, F. PeDantec in his "Individual evolution, heredity and neo-Darwinians "described the Telegenic phenomenon - influence of the first male animals (the influence of fertilization and pregnancy from the first sexual partner for signs of offspring at risk of pregnancy). Conducted numerous studies have confirmed the findings. So, Professor, Doctor of Medical Sciences Barabash, writes that "a priori by our ancestors knew: the first in a woman's life leaves a sexual encounter in the genetic heritage trail the rest of her life ... Those who have lived in unlimited sexual freedom, the people gradually degenerated and disappeared. No Samnites and Etruscans, who are mired in debauchery, once mighty Roman Empire agonizing in mass orgies, killing the Hittites, the Aztecs, and many others. The scheme is one of degeneration: a mass prostitution sexual perversion - Mental attitude - the inability to produce healthy children "[Health Science 1997, p.50-51]. These data again emphasize the need for a return to moral principles bequeathed by our ancestors.

In our time, morality is experiencing an unstable state, which corresponds to the fourth phase in the evolution of the cone model: in this phase, there may be very different and mutually exclusive states. But in the general state of imbalance and chaos is the condition for the transition to a new state of order and harmony. What would be the point of this transition polifurcations depends on a small increment in the human psyche - the moral and spiritual component to add up all the people of the world will create the conditions for the onset of the evolutionary path of development. That is why it is necessary to immediately and radically restructure the entire system of education and training and the basis for this adjustment to put focus on the revival of spiritual and moral principle. Otherwise, humanity can stand before his disappearance from the face of the Earth. No other age does not create such brilliant opportunities for moral heroism, as no other does not create moral hazard of such ugliness. The truth and fearless ability to look reality in the eye in the most intricate provisions of life - so should be the first requirement of morality. Therefore, it is important to prepare in the sphere of morality of these fighters evolution. The purpose of moral education and training should be to create the perfect personality, able to take on the shoulders of everyday work for the benefit of mankind. We are faced with specific training objectives of people coming period, the next generation in line with the historical role that falls to their lot.

The above requires significant changes in the content of education. It has to focus on the national culture, national contain myths and legends, history, destiny, and the calling of the way of the people, things and words of saints, heroes, geniuses, language and literature, customs and ceremonies, national architecture, design and art. In the words of the poet Yevgeny Yevtushenko, the function of great art - is a function of the bell, waking the slumbering conscience. Therefore, we believe that there should be communication with the true cultural values, with the most beautiful works of art, carrying the light of the High Knowledge, Wisdom, Morality, which ennoble the soul, filling and clearing it with Light, Love and Beauty. It is in this process of interaction between humanity and the natural form of collective morality moral qualities of competence of a particular person is the improvement of the individual.

Art is the expression of the Beautiful. As a means of understanding the world, it is the education and upbringing. However, the art brings people together, unites them, and helps us to understand both themselves and others. Formation of moral development at its core is based on empathy properties of the individual, the individual's ability to reflect. Around the experiencing person creating a special field that is collected on the basis of communicative interactions surrounding the identity of people. Depending on the individual qualities of empathy is the response to the experiences of a particular individual. The highest form of empathy means the full interpersonal identification. This form of empathy is the highest form characterizes both psychological and moral nature of man. Feelings developed person should be able to dissolve in the social and meaningful experience, while at the same time are able to manifest itself in the individual experience and reflection, when a man is alone with his conscience.

These psychological mechanisms of education in the human qualities of empathy are the basis for the creation of strong and friendly relations between the peoples of the planet. And so we can say that there are more effective than the Conference on Disarmament, the means to solve the global problem of the peaceful coexistence of people in the world - 
a world through international cultural contacts. Mezhelaytis wrote that the great and true art brings people together makes them brothers. Hence, in our view, the need to raise to the highest level of significance in the educational process of introducing daily positive contact with the culture, priorities and cultural congruence of teaching spaces.

\section{Results and Discussion}

Thus, the educational process must be based on spiritual resources of society and spiritual and moral potential of human beings in accordance with, and should build the educational process at all levels. In the same university education programs are required to form not only the knowledge, skills, and personal qualities but which will form the basis of competence, as shown in Figure 1 (a circle is limited to the knowledge society, in the form of the house shows the university). This should be the response to the new demands of economic and social demands of the time. The result will be created with the competence of the individual creativity of new technologies that will change the approach to solving global problems. It is necessary, first of all, to meet the very prosaic needs for food, drink, clothing, shelter, work, etc., in terms of population explosion and consequent overcrowding in major cities especially requiring immediate resolution. Based on this approach be followed by the solution, and other global issues at both the national and the multicultural levels. It is this strategy that we believe will be possible to realize the powerful potential of the world's talent (and maybe even "geniuses sleeping", which is concentrated in universities and for the manifestation of which must be in the educational process of higher education established corresponding social conditions.

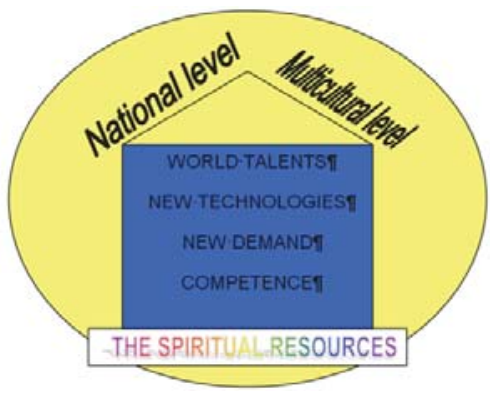

Figure 1 - The spiritual resources - the basis of the prosperity of mankind

In our opinion, should be guided by the position that traditionally education has always been understood as a process of cultural education rights in accordance with the ideal representations of a particular society of spiritual and moral values. Expression of these ideas is an art. Artistic images reveal and develop the best qualities in a man, take up the arts as a spiritual culture. The fruit of such education is an inner harmony, agreement between duty and desire, between reason and emotion. In pedagogical opinion, it is important that art as a "ready" the body to a particular action.

Furthermore, it should be noted that the work of art as material objects carry the energy of the creative activities of the people who create them. And the more spiritual and moral was an author, the more powerful healing effect on human exercise he created works of art. Once he had seen the product may have on the subconscious mind of a young growing body lasting impact, creating a special feeling in his entire inner world. Therefore, the selection of works of art should be the most highly moral criteria, as well as familiarity with them should take place in a state of solemnity and harmony. The most brilliant works of art can initiate an entire era, the spiritual development of a whole generation of people coming into contact with it. Therefore, these works of genius must be carefully guarded, because the standards are a key spiritual and moral development and evolution.

It should also be noted that works of art are essential color- and sound therapeutic impact on mental and physical health of the emerging between education rights. The formation of self-awareness and enrichment of the intellectual world in adolescence is accompanied by new experiences; the samples were thinking that boys and girls are looking at works of art. During dialogue with the art they have created not only a special artistic ability, but there is a movement and a significant adjustment in the moral sphere. Admiring the work of art, like a man enters into it, identifying himself with it and going from itself. This is the cathartic power of art.

Research carried out by us [Motornaya 2009, 1997] have shown that with the increase of ownership of the art is an intensive educational enrichment range of interests, increase in the percentage of students of students well, and finds a close connection to the art of belonging to scientific creativity. Artistic activity of students at a high enough level bringing 
them to the art of becoming a reliable barrier against the manifestations of "spiritual deficit", which is that the students have time low, they have no interest in the arts, the perception of which requires the necessary spiritual work; preference in the literature and Film is given militants, horror, entertainment genre. However, classes, which are based on the spiritual and practical attitude to the world of art, with a focus on reproductive activity, develop experience of co-creation, collaboration.

In our view, as the main methodological position, providing the implementation of the evolutionary ideas of education, should act modeling art and the creative process, when a student, regardless of his future profession, is put in the position of creator-composer-creator of the poet, the creator, the artist, the creator a director, creating works of art for yourself and for other people. Modeling artistic creative process manifests itself in the passage way of birth artwork, recreating it as an "inside" and living the moment of re-creation. One of the most effective and modern training facilities capable of realizing the artistic and creative modeling process based on the principle of general didactic clarity, is the use of multimedia technology in the classroom, which brings together within a single computer system of text, sound, video, graphics and computer animation. Such series can be effectively applied to the lectures and practical exercises to enhance all channels of perception student, for the harmonization of the right and left hemispheres of the cerebral cortex, to create the conditions for the activation of phase rotation and relaxation in the brain, which in turn leads to improve student performance, the development of the creative process in the classroom, outside the box thinking, self-reliance, images of beauty - the development of spirituality and morality. All together - to improve, to build skills needed for effective work for the benefit of society and humanity.

\section{Conclusions}

Thus, as the main power line and guiding evolution, moral and spiritual perfection of man in general, and determines the development of pedagogy and education, the choice of principles, methods, forms and means of implementation of the educational process, culture and the arts as a core around which to teaching and educational process of forming the elements of didactics; psychocompetization process of filling the spiritualizing and pedagogical space.

\section{Recommandation}

Our further research, we see the development of specific lectures and practical classes on the basis of the best works of art and culture, leading to the development of spiritual and moral potential of the student. For the "separate issue from the question of the moral of the art is just as impossible as the fire spread to the light, warmth and strength burning" [Belinsky 1953, p.406].

\section{References}

Belinsky, V. Menzel, critic Goethe. Full. Works. Op. T. 3. - Moscow: Publishing House of the USSR Academy of Sciences, 1953. - p.406. Delors, J. Learning: the treasure. Report of the International Commission on Education for the XXI Century, submitted to UNESCO. Moscow: AST; Kharkiv: Folio, 2004. - 678 p.

Kagan, M. Philosophy of Culture. - St. Petersburg. Univ "Lan", 1996. - pp.319-330.

Motornaya, S. Modern scientific basis of psychocompetization of evolutionary variation of Higher education. - Sevastopol Univ "Weber", 2009. $-452 \mathrm{p}$.

Motornaya, S. The study of evolutionary variability of knowledge and comprehension in the space of Higher school. SevGTU Herald. Ser. Pedagogy: Collecnion of scientific papers. - Sevastopol, 2010. - №.104. - pp.19 - 25.

Motornaya, S. Pedagogical conditions of formation of psychological readiness of students of technical High school to professional activity: PhD dis: 13.00.01 /Motornaya Svetlana E. - Tomsk, 1997. - 204 p.

Motornaya, S. \& V. Marigodov. Pedagogy and Psychology: enhancing aspects of creativity and readiness for professional work: Textbook for students of Technical High School - K.: PH "Professional", 2005. - 192 p.

Motornaya, S. marginalization and the Evolution of Consciousness, INTERSTUDIA: Semestrial review of the interdisciplinary center for studies of contemporary discursive forms. Margins, marginalization and the discourse of marginality, Alma Mater Publishing House. Bacau. Romania, № 13, 2013. pp.136-144.

Motornaya, S. Higher Education And Translators Training Problem In The Modern Globalized World. Science, Technology and Higher Education [Text] : materials of the international research and practice conference, Vol. II, Westwood, December 11th-12th, 2012 I publishing office Accent Graphics communications - Westwood - Canada, 2012. - pp. 115-118.

Motornaya, S. Evolutionary variability of English and American Literatures in Space of cognition and its implementation in life. Academy of knowledge: scientific journal / [ed. FV Lazarev]. - Simferopol, 2011. - 130 c. - №1-2. - pp.113-120.

Motornaya S. The Role of Culture in the development of moral-ethical sphere of technical university future graduates competitive 
personality in the Education training process. SevGTU Herald. Ser. Pedagogy: Collecnion of scientific papers. - Sevastopol, 2010. - №.105.

Raimundo H. Higher Education in Latin America // Higher Education in Europe. - 2003. - № 1. - pp. 16-21.

Science Health: Textbook for the course "Valeology" for secondary and higher education institutions. - Tomsk: Banner of Peace, 1997. $110 \mathrm{p}$.

Sorokin, P. People. Civilization. Society. - M.: Politizdat, 1992. - 545 p.

Chernilevsky, D. Pedagogy of higher education. - M.: Mechanical Engineering, 2005. -702 p. 